TIPBURN SYMPTOMS IN LETTUCE

\author{
G.P. Termohlen and A.P. v.d. Hoeven
}

Horticultural and Experimental, Station, Naaldwijk

Tipburn in lettuce occurs in the crops under glass as well as in the open. It is promoted by unfavourable growing conditions.

Till last year a surplus of transpiration as compared with the water uptake has generally been considered as the main cause of tipburn. The symptoms were severe on soils with a high salt concentration.

It appeared afterwards that different tipburn symptoms occur which do not have necessarily the same cause. These symptoms are more or less severe in the different seasons.

Therefore it is worthwhile to mention briefly the types of lettuce growing during the year, to be followed by a discussion about the tipburn symptoms which could be distinguished till now. Lettuce growing is a year-round-production.

Under glass lettuce is harvested from October till June and in the open from May till the end of October. In April and May there is also some frame-lettuce.

Till now the following tipburn symptoms could be distinguished.

I emphasize the fact that the different symptoms can occur in every season. However, the frequence of occurrence depends on the season. Much work has still to be done on the environmental conditions promoting and preventing tipburn and on the anatomical changes in the lettuce leaves.

\section{"Dry-tipburn" (droogrand)}

Dry tipburn occurs mainly in crops near maturation when the transpiration of the leaves exceeds the water uptake by the roots.

The outer leaves show small brown lesions along the margins or margins which are completely brown (Fig. 1). The first symptom is a curling of the leaf margins in such a way that the undersides of the leaves become visible, the cause being a check in growth. In this stage of development some very small brown spots may be found. The symptoms of dry tipburn mostly occur in autumn and winter crops. Possibly growth checks, especially to be found in these seasons, promote the beginning of dry tipburn.

On soils desinfected before planting, either by steaning or by chloropicrin treatment, the occurrence of dry tipburn often is severe. The influence of soil desinfection on a lettuce crop is more unfavourable as the soil is less suitable for lettuce growing. In fact, in these cases the crop becomes less firm and thus more susceptible. Aiso a vigorous growth will make the plants susceptible.

If, in case of frost, more heat is given, the conditions for the appearance of dry tipbum are more favourable. In glasshouses with heating pipes in low position, the lettuce heads near the pipes become attacked sooner and more severe than the heads at greater distances from the pipes.

The control is achieved by providing a regular growth, which is the more important near crop maturation. Good growing conditions for the roots are very important. When the crop is susceptible to tipburn, the water uptake should be promoted and a transpiration excess be prevented. It is then necessary to irrigate the crop before starting heating and recommendable to give a short sprinkler irrigation when more heat is required.

\section{"Normal tipburn" (Gewoonrand)}

In former days most lettuce was grown in spring. The name tipburn originates from that time; later on, after appearance of different tipburn types, the original type was called normal tip- 
burn.

This tipburn type also occurs when the water uptake by the roots is insufficient in cases of a sudden heavy increase of the transpiration. Especially during sharp sunny and dry weather normal tipburn can occur very severe. This is one of the reasons that normal tipburn occurs mainly in spring crops.

The development of dry tipburn is slower than the development of normal tipburn, which might occur all of a sudden from one day to another. The symptoms of normal tipburn become visible on the leaves enclosing the head and on the leaves just underneath (Fig. 2). The first symptoms are small transparent lesions along the sriall veins near the leaf margins. The leaf margins become flaccid and afterwards turn brown. On soils which are too dry and on soils with a high salt concentration normal tipburn occurs soon and severe. In these cases the water uptake is in the minimum surely.

Crops grown at high night temperatures (vigorous growth) are more susceptible, especially near maturation.

Some preventive control measures are: growing a firm crop; extra irrigation on critical days; screening the sunlight to prevent too high temperatures and a too heavy transpiration.

\section{"Veinal tipburn" (nerfrand)}

Veinal tipburn often occurs in late autumn and winter crops, when the transpiration is insufficient, by which the humidity in the head becones too high. This is the case after a long period of dull and moist weather. At first the young leaves show a die back of the top veins; this necrosis rapidly spreads via the veines (Fig. 3). Finally the leaf tissue becomes necrotic.

Antecedent to the necrotic symptoms the phenomenon of glassy leaves often can be observed; the intercellulars are filled with water instead of air. This glassiness may either disappear, or be followed by a necrosis of the veins and the leaf tissue. In certain cases only the part of some leaves near the stem shows glassy tissues due to a too high humidity in the head; this tissue soon turns yellow, followed by browning and rotting.

The transpiration can be stimulated by heating with slightly opened ventilators. The leaves in the head become then drier, thus diminishing the glassiness and the occurrence of veinal tipburn. Irrigating should be done if the weather is bright and drying.

\section{"Latex tipburn" (stippelrand)}

The first stage of latex tipburn is the release of latex droplets near the margins of young leaves, mainly on the undersides of the leaves. The symptoms only occur on leaves enclosed in the head. The latex oxidizes and turns brown, the ultimate result being sunken necrotic lesions (Fig. 4).

Experiments showed that the occurrence of latex tipburn is correlated with the change of the plant from the vegetative stage into the generative stage. Symptoms of this tipburn type can be very severe in bolting lettuce heads. Latex tipburn could be evoked within half an hour on young leaves of plants which just have entered the generative stage. For this purpose the plant was covered with plastic and the temperature was raised simultaneously by an electric bulb. Without increasing the temperature the symptoms failed to cone.

In late spring crops under glass and in summer crops in the open, latex tipburn is sometimes very severe. In these crops the plants enter the generative stage rather early.

The necrotic tissue rots soon; the rotting spreads rapidly due to the high humidity in the head.

The only control is to prevent near crop maturation high humidities and high temperatures. High temperature work two-fold: they promote the release of latex and the generative development of the lettuce head.

In autumn and winter crops the fungus Pleospora herbarum may cause disease symptoms which resemble tipburn. However, the necrotic lesions usually are larger. The development of the fungus is promoted by high humidities. Heating and ventilating may prevent this disease.

Except dry tipburn, all tipburn types (including attack of the fungus Pleospora) often give rise to rotting, sometimes together with Botrytis attack. This makes the heads completely valueless. 


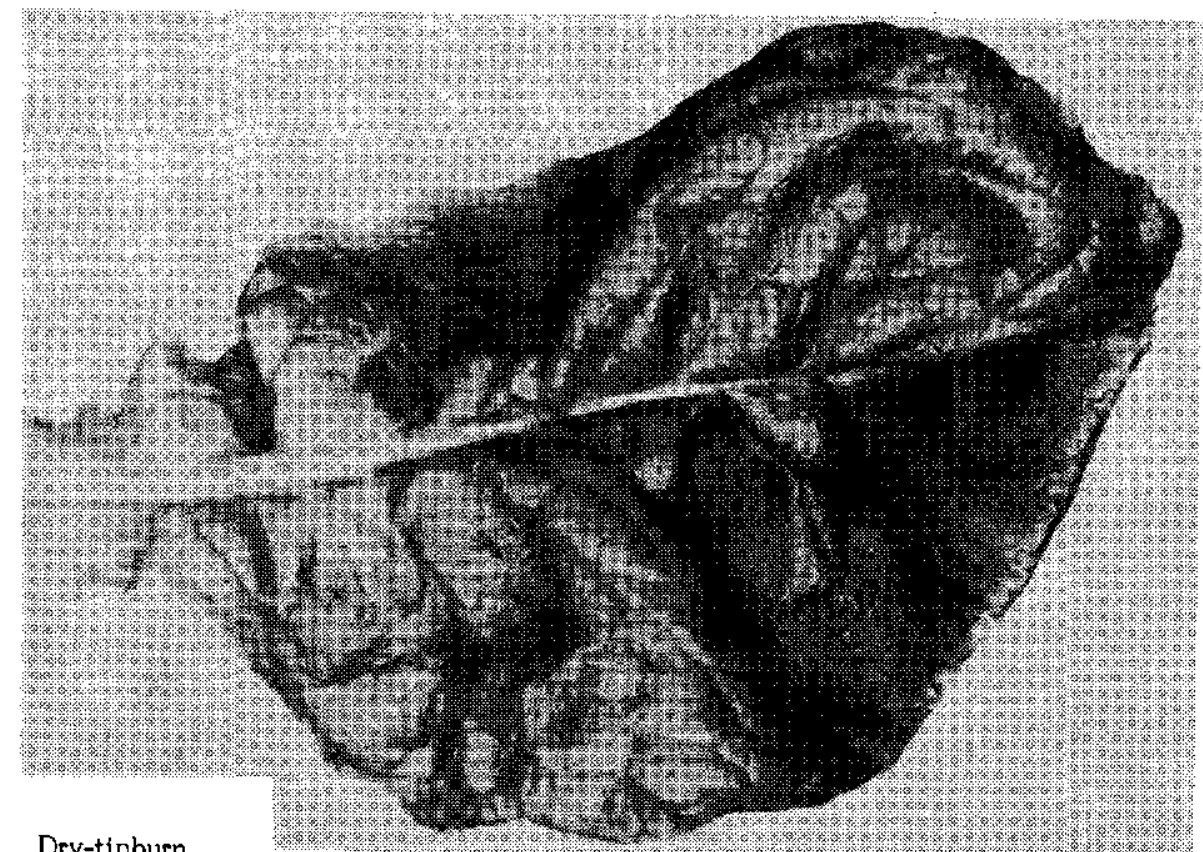

Fig. 1 Dry-tipburn



Fig. 2 Normal tipburn 
Fig. 3 Veinal tipburn
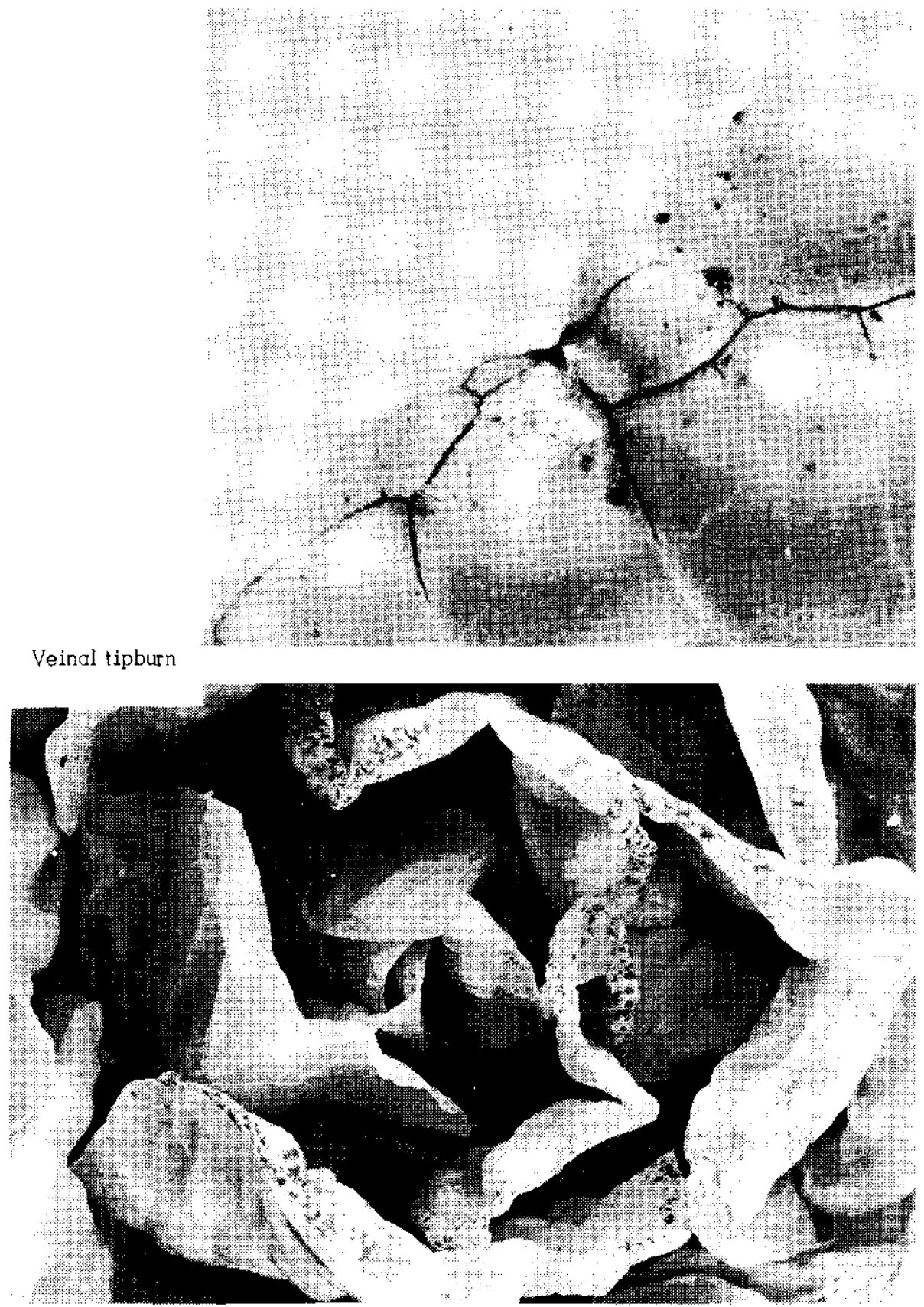

Fig. 4 Latex tipburn 